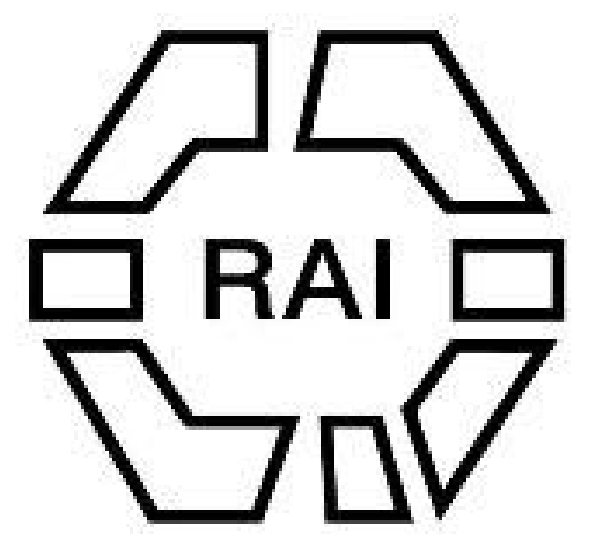

\title{
WILEY
}

54. Mr. Mathew's Theory of Australian Phratries.

Author(s): Andrew Lang

Source: Man, Vol. 11 (1911), p. 85

Published by: Royal Anthropological Institute of Great Britain and Ireland

Stable URL: http://www.jstor.org/stable/2840740

Accessed: 20-06-2016 22:00 UTC

Your use of the JSTOR archive indicates your acceptance of the Terms \& Conditions of Use, available at

http://about.jstor.org/terms

JSTOR is a not-for-profit service that helps scholars, researchers, and students discover, use, and build upon a wide range of content in a trusted digital archive. We use information technology and tools to increase productivity and facilitate new forms of scholarship. For more information about JSTOR, please contact support@jstor.org.

Royal Anthropological Institute of Great Britain and Ireland, Wiley are collaborating with JSTOR to digitize, preserve and extend access to Man 
Australia : Sociology.

Mr. Mathew's Theory of Australian Phratries. By Andrew Lang.

In the Journal of the Anthropological Institute, Vol. XL, pp. 165 to 171, the Rev. John Mathew again sets forth his theory of the origin of phratries, and of some phratry names in Australia. The theory is, that "the two phratries represent "two ancient distinct races"-one of them, "Papuasian, very dark, with curly hair"; the other, "a stronger, more advanced, lighter-coloured race, with straight hair, and " akin to the Dravidians and Veddahs."

An obvious question arises. We meet phratries, or exogamous intermarrying sets of people, in many parts of the world. Are all these phratries the result of a combination of two distinct human races? If not (and Mr. Mathew, perhaps, ought to scrutinise all known phratries), why are we to suppose that phratries in Australia are, the result of a combination with connubium of two races, primarily distinct? An institution so very widely extant, in lands so far remote, as the phratry is, is likely to have arisen in some "felt need" other than the peaceful coalition of two separate races.

Mr. Mathew gives evidence, proving that among the Euahlayi, in Western Australia, and in Queensland, and in Victoria ( $\mathrm{I}$ state the case as briefly as possible), phratry names indicate contrasts in colour or complexion- "light blood" and "dark " blood" - and that old blacks believe they can tell the phratry of an individual by the quality of his hair, straight or curly. Mrs. Bates, I may add, has kindly given me much information to the same effect : nor do I question her accuracy. The light phratry, therefore, it seems, inherits the complexion and hair of one of Mr. Mathew's two ancient races; the dark phratry inherits the hair and complexion of the other ancient race. But have we not here a question for physiologists? Say that, in an isolated region, a thousand negroes and a thousand Scandinavians combine as two phratries, one "dark" (the negroes), the other "white" (the Danes). Black marries white alone; white marries black alone, for ever.

In the second generation all are equally mulattoes. How could you tell to which phratry (given reckoning by female descent) any mulatto individual belonged? In ten generations all would be coffee-coloured (café au lait), and how could you tell to which phratry any individual belonged? Each individual belongs to both by descent; the black blood and the white blood are equally in his or her veins.

Where distinctions of complexion are so much less marked, as among Mr. Mathew's two ancient races, both dusky, how can the distinction survive through the eternal combination of both races under the phratry system?

That many tribes have phratries named after birds of contrasted colours $\mathrm{Mr}$. Thomas and I have pointed out some time ago. But I do not think that philological guesses, applied to discover the meanings of phratry names of unknown sense, can do anything but darken causes.

For the rest, I leave to physiologists the question : After long and exclusive intermarriage between negroes and Danes, could the members of black phratry be distinguished, in the same environment, from the members of the white phratry?

ANDREW LANG.

\section{Africa, East.}

A Note on “Hammer-Stones." By B. W. Walker, M.D.

When visiting Nasa and other villages at the south end of Victoria Nyanza 44 in German East Africa from 1887 to 1907 Mr. R. H. Walker, of the Church Missionary Society in Uganda, noticed that the native women there had a special use for a hammer-stone, several of which he obtained as specimens.

These stones become absolutely spherical from constant use, being turned about 